Jurnal Penelitian, Vol. 10, No. 2, Agustus 2016

\title{
ANALISIS MODEL FUNDRAISING DAN DISTRIBUSI DANA ZIS DI UPZ DESA WONOKETINGAL KARANGANYAR DEMAK
}

\author{
Murtadho Ridwan \\ Sekolah Tinggi Agama Islam Negeri (STAIN) Kudus \\ adle_hr@yahoo.com
}

\begin{abstract}
The success of the collection and distribution of ZIS funds determined by the management of fundraising and distribution adopted by the institution of zakat. There are several models of fundraising and distribution of ZIS funds that can be applied in managing the ZIS funds. UPZ is one part of the organization's most end zakat according to our regulations. UPZ has the authority to collect zakat and charity donation fund. This article aims to analyze the model of fundraising and distribution of ZIS funds in UPZ Wonoketingal village, Karanganyar, Demak. The approach used is a qualitative approach to observation, interviews, and documentation as methods of data collection. When the analysis of the data used is the analysis model of Miles and Huberman. The results showed that fundraising in the UPZ Wonoketinggal village combining two models, namely direct and indirect fundraising. Indirect fundraising is used to promote the program through announcements in lectures, town hall or at the time of Jumu'ah prayer. And direct fundraising committee UPZ done by visiting the houses of citizens directly. While the distribution model of ZIS funds applied consumerist traditional models and creative productive models. Consumptive traditional models used to distribute zakat fitrah, zakat mal for the poor, and funds charitable donation. While creative productive models used for the distribution of zakat mal for gharim.
\end{abstract}


Keywords: Fundraising, Distribution, Zakat, Infaq, Shadaqa.

\begin{abstract}
Abstrak
Keberhasilan pengumpulan dan pendistribusian dana ZIS ditentukan oleh manajemen fundraising dan distribusi yang dianut oleh lembaga zakat. Ada beberapa model fundraising dan distribusi dana ZIS yang dapat diterapkan dalam mengelola dana ZIS. UPZ adalah salah satu bagian dari organisasi pengelola zakat yang paling akbir menurut regulasi kita. UPZ memiliki wewenang untuke mengumpulkan dana zakat dan dana infak sedekah. Artikel ini bertujuan untuk menganalisis model fundraising dan distribusi dana ZIS di UPZ desa Wonoketingal Karanganyar Demak. Pendekatan yang digunakan adalah pendekatan kualitatif dengan observasi, wawancara, dan dokumentasi sebagai metode pengumpulan data. Manakala analisis data yang dipakai adalab analisis model Miles and Huberman. Hasil kajian menunjukkan babwa UPZ Desa Wonoketinggal menggabungkan dua model fundraising, yaitu direct fundraising dan indirect fundraising. Indirect fundraising digunakan untuk mensosialisasikean program melalui pengumuman di pengajian, pertemuan warga ataupun pada saat solat Jumu'ah. Dan direct fundraising dilakukan pengurus UPZ dengan cara mendatangi rumah warga secara langsung. Sementara model distribusi dana ZIS yang diterapkan UPZ Desa Wonoketingal adalah model konsumtif tradisional dan model produktif kreatif. Model konsumtif tradisional digunakan untuk mendistribusikan zakat fitrah, zakat mal bagi fakir miskin, dan dana infak sedekah. Sedangkan model produktif kreatif digunakan untuk distribusi dana zakat mal bagi gharim.
\end{abstract}

Kata Kunci: Fundraising, Distribusi, Zakat, Infak, Shadaqah.

\title{
A. Pendahuluhan
}

Kewajiban zakat dengan tegas diperintahkan Allah dalam berbagai firman-Nya. Zakat ditunaikan oleh mereka yang mengharapkan balasan Allah di akhirat, dan kadang-kadang ditinggalkan oleh mereka yang kurang yakin terhadap balasan akhirat. ${ }^{1}$ Zakat bukan hanya sekedar rukun Islam, tetapi juga sebagai penentu apakah seseorang itu menjadi saudara seagama

${ }^{1}$ Yusuf al-Qardhawi, Musykilah al-Faqr wa Kaifa Alajaha al-Islam, (Beirut: Muassasah al-Risalah, 1985), hlm. 87. 
atau tidak.

Dilihat dari sisi hikmah, zakat memiliki dua dimensi, dimensi vertikal dan dimensi horizontal. Artinya, zakat menjadi perwujudan ibadah seseorang kepada Allah dan juga sebagai perwujudan dari rasa kepedulian sosial (kesalehan sosial). Membayarkan zakat adalah urusan individu sebagai pemenuhan kewajiban seorang muslim dan itu merupakan urusan kepada Allah. Namun dalam melaksanakan kewajiban tersebut, orang yang membayar zakat (Muqakki) tidak bisa terlepas dari urusan bersama (horizontal), karena zakat berkaitan dengan harta benda dan kepada siapa harta itu diberikan, sehingga sangat berkaitan dengan para penerima (Mustabiq).

Dalam pelaksanaanya, zakat harus diatur dan ditetapkan oleh agama dan negara, baik dari segi jenis harta yang wajib dikeluarkan, para wajib zakat (Muqakki), para penerima zakat (Mustabiq), sampai pada pengelolaan zakat oleh pihak ketiga. Dalam hal ini pemerintah atau lembaga yang ditunjuk oleh pemerintah untuk mengelola zakat akan membantu para Muzakki untuk menyampaikan zakatnya kepada para Mustabiq atau membantu para Mustahiq dalam menerima hak-haknya.

Selain zakat, kita juga dianjurkan untuk berinfak dan bersedekah. Tujuannya adalah untuk membersihkan harta dan hati kita agar terhindar dari sifat sombong dan kikir karena baik infak maupun sedekah dilakukan dengan sukarela. Allah SWT menjamin harta yang kita keluarkan tidak akan berkurang, bahkan akan diganti dengan nikmat yang berlipatganda. Apabila seseorang dikaruniai rezeki yang berlimpah, sebaiknya diimbangi dengan selalu berinfak dan bersedekah sebagai rasa syukur dan terima kasih kita kepada Allah SWT.

Di Indonesia pengelolaan zakat diatur berdasarkan Undang-undang No. 23 Tahun 2011 tentang Pengelolaan Zakat dimana Undang-undang tersebut menyatakan bahwa untuk melaksanakan pengelolaan zakat, Pemerintah membentuk BAZNAS baik di tingkat Pusat, Propinsi dan Kabupaten Kota. ${ }^{2}$ Dan untuk membantu tugasnya, BAZNAS boleh membentuk

${ }^{2}$ Undang-undang No. 23 Tahun 2011 Tentang Pengelolaan Zakat. 
Unit Pengumpul Zakat (UPZ) di tingkat kecamatan atau desa dan yang lain.

Salah satu UPZ Desa yang memiliki kesungguhan dalam mengelola dana ZIS adalah UPZ Desa Wonoketingal Kecamatan Karanganyar Kabupaten Demak. UPZ ini sudah didirikan sebelum Undang-undang zakat diperbarui. UPZ Desa Wonoketingal tidak hanya mengumpulkan dana zakat saja, namun juga mengumpulkan dan infak sedekah. Dari hasil observasi didapatkan bahwa ada dua kegiatan utama dari UPZ ini yaitu fundraising dan distribusi dana ZIS. Jenis dana ZIS yang dikelola pun beragam seperti zakat mal, zakat fitrah, dana santunan anak yatim, dan dana kurban.

Pada tahun 2015, dana ZIS yang dikelola oleh UPZ Desa Wonoketingal mencapai Rp 632.989.200,--.3 Jumlah tersebut cukup besar bagi sebuah UPZ Desa sehingga artikel ini akan menganalisis model fundraising dan distribusi dana ZIS di UPZ tersebut untuk mengidentifikasi model fundraising dan distribusi dana ZIS sehingga bisa diterapkan di UPZ-UPZ yang lain.

\section{B. Pembahasan}

\section{Manajemen Fundraising Dana ZIS}

James F. Stoner seperti yang dikutip oleh Sri Budi Cantika Yuli menjelaskan bahwa manajemen adalah proses perencanaan, pengorganisasian, dan penggunaan sumber daya-sumber daya organisasi lainnya agar mencapai tujuan organisasi yang telah ditetapkan. ${ }^{4}$ Ada dua model manajemen yang bisa diikuti, yaitu:

a. Management by Result (MBR), adalah gaya manajemen yang menekankan pada hasil.

b. Management by Process (MBP), adalah gaya manajemen yang menekankan pada pentingnya penataan proses dan berorientasi pada jangka panjang.

Management by Process (MBP) sangat tepat digunakan oleh

${ }^{3}$ Hasil observasi. Tidak semua dana ZIS yang terkumpul di UPZ Desa Wonoketingal berupa uang, tapi mayotitasnya berupa barang.

${ }^{4}$ Sri Budi Cantika Yuli, Manajemen Sumber Daya Manusia, (Malang: UMM Press, 2005), hlm. 5. 
Organisasi Pengelola Zakat (OPZ). Karakter dasar MBP sangat tepat karena bisa memberi kesempatan pada semua pihak untuk berpartisipasi, dimana kualitas Amil dan Mustahiq ditingkatkan, dan tidak ada pihak manapun yang dirugikan. ${ }^{5}$

Masyarakat masih berpandangan bahwa manajemen belum perlu diterapkan dalam mengelola zakat. Ini karena zakat masih di anggap sebagai persoalan ringan yang tidak perlu dikelola secara profesional. Apalagi, ketika disebut zakat, orang segera mempersepsikan zakat fitrah dalam benaknya dan zakat fitrah cukup dilaksanakan di akhir bulan Ramadhan. ${ }^{6}$

Untuk menggairahkan organisasi zakat, tidak bisa tidak, kita harus menerapkan manajemen modern. Kita bisa mengambil model manajemen sederhana yang dipelopori oleh James Stoner, sebagai proses perencanaan (planning), pengorganisasian (organizing), pengarahan (actuating), dan pengawasan (controling). Empat aktifitas menejemen bisa dijelaskan secara singkat sebagai berikut. ${ }^{7}$

Pertama, Perencanaan (planning), merupakan suatu aktifitas untuk membuat rancangan-rancangan agenda kegiatan yang akan dilakukan oleh sebuah organisasi. Dalam lembaga zakat, rencana strategis merupakan suatu unsur yang tidak bisa dipisahkan. Ada beberapa alasan tentang hal itu, di antaranya adalah masalah kepercayaan, masyarakat, dan pemeliharaan.

Kedua, Pengorganisasian (organizing), merupakan cara yang ditempuh oleh sebuah lembaga untuk mengatur kinerja lembaga termasuk para anggotanya. Dalam lembaga zakat, kita akan bertemu dengan orang-orang yang memiliki tendensi yang berbeda. Apapun alasan orang untuk ikut terjun dalam dunia pengelolaan, saat bicara organisasi, semua kepentingan yang mengatasnamakan pribadi atau golongan harus dibuang jauhjauh.

${ }^{5}$ Uzaifah, "Manajemen Zakat Pasca Kebijakan Pemerintah Tentang Zakat Sebagai Pengurang Penghasilan Kena Pajak", Jurnal Ekonomi Islam, Vol. IV, No. 1, Juli 2010, hlm. 54.

${ }^{6}$ Sudirman, Zakat dalam Pusaran Arus Modernitas, (Malang: UIN-Malang Press, 2007), hlm. 27.

${ }^{7}$ Ibid., hlm. 79-93. 
Ketiga, Pengarahan (actuating), merupakan proses penjagaan agar pelaksanaan program kegiatan dapat berjalan sesuai dengan rencana. Dalam pelaksanaan ada beberapa komponen yang sangat diperlukan, diantaranya adalah motivasi, komunikasi, dan kepemimpinan.

Keempat, Pengawasan (controlling), merupakan proses untuk menganjurkan aktifitas positif dan mencegah perbuatan yang menyalahi aturan. Dalam lembaga zakat, pengawasan setidaknya ada dua substansi, yaitu pengawasan secara fungsional dan pengawasan secara formal.

Menurut Eri Sudewo seperti yang dikutip oleh Uzaifah, manajemen pengumpulan zakat dibedakan menjadi dua, yaitu; manajemen fundraising dan layanan donatur. ${ }^{8}$ Manajemen fundraising yang dimaksud meliputi:

a. Kampanye, proses kampanye adalah proses membangkitkan kesadaran pembayaran zakat.

b. Kerjasama program, kerjasama bisa dilakukan dengan lembaga atau perusahaan lain yang berbentuk aktivitas fundraising.

c. Seminar dan diskusi, dalam sosialisasi zakat, galang dana juga dapat melakukan kegiatan seminar atau diskusi dengan tema yang relevan dengan kegiatan dan kiprah organisasi pengelola zakat.

d. Pemanfaatan rekening bank, maksudnya memberikan kemudahan donatur menyalurkan dana.

Sedangkan manajemen layanan donatur yang dapat dilakukan oleh pengelola zakat adalah sebagai berikut:

a. Melakukan pendataan donatur dengan sistem dokumentasi yang rapi.

b. Menerima keluhan donatur dan masyarakat luas.

c. Follow up keluhan-keluhan yang ada.

Sama dengan yang disampaikan Eri Sudewo, kampanye menjadi salah satu bagian manajemen fundraising dana ZIS. Langkah-langkah kampanye yang dapat dilakukan antara lain

${ }^{8}$ Uzaifah, "Manajemen Zakat Pasca Kebijakan Pemerintah Tentang Zakat Sebagai Pengurang Penghasilan Kena Pajak", hlm. 55. 
dengan melakukan sosialisasi melalui:

a. Media massa

b. Film dan Video

c. Leaflet/brosur/booklet

d. Portal website

e. Billboard/banner/baliho/spanduk

f. Khutbah Jum'at

g. Orientasi pengurus lembaga pengelola zakat

h. Gerakan sadar zakat

i. Desa binaan zakat

Adapun dalam melaksanakan kegiatan fundraising, banyak model dan teknik yang bisa dilakukan. Pada dasarnya model fundraising dapat kelompokkan menjadi dua. ${ }^{9}$ Pertama, Direct fundraising yang diartikan dengan model yang menggunakan teknik-teknik atau cara-cara yang melibatkan partisipasi Muzakei atau donatur secara langsung. Yaitu bentuk-bentuk fundraising dimana proses interaksi dan daya akomodasi terhadap respon Muzakki atau donatur bisa seketika (langsung) dilakukan. Dengan model ini apabila dalam diri Muzakei muncul keinginan untuk melakukan donasi setelah mendapatkan sosialisasi dari fundraiser lembaga, maka segera dapat melakukan dengan mudah dan semua kelengkapan informasi yang diperlukan untuk melakukan donasi sudah tersedia. Sebagai contoh dari model ini adalah: Direct Mail, Direct Advertising, dan Telefundraising.

Kedua, Indirect fundraising, yaitu suatu model yang menggunakan teknik-teknik atau cara-cara yang tidak melibatkan partisipasi Muqakki atau donator secara langsung. Yaitu bentuk-bentuk fundraising dimana tidak dilakukan dengan memberikan daya akomodasi langsung terhadap respon Muzakki atau donator seketika. Model ini misalnya dilakukan dengan metode promosi yang mengarah kepada pembentukan citra lembaga yang kuat, tanpa diarahkan untuk transaksi donasi pada saat itu. Sebagai contoh dari model ini adalah:

${ }^{9}$ April Purwanto, Manajemen Fundraising bagi Organisasi Pengelola Zakat, (Yogyakarta: Sukses, 2009), hlm. 12. 
advertorial, image compaign dan penyelenggaraan Event, melalui perantara, menjalin relasi, melalui referensi, dan mediasi para tokoh. ${ }^{10}$

\section{Manajemen Distribusi Dana ZIS}

Agar dapat berdayaguna dan berhasil guna, maka pemanfaatan dana ZIS harus selektif untuk kebutuhan konsumtif atau produktif. Oleh sebab itu manajemen distribusi dana ZIS membedakan empat model distribusi sebagai berikut: ${ }^{11}$

Pertama, Konsumtif tradisional, maksudnya zakat dibagikan kepada Mustabiq secara langsung untuk kebutuhan konsumsi sehari-hari, seperti pembagian zakat fitrah berupa beras dan uang kepada fakir miskin setiap hari raya Idul Fitri atau pembagian zakat Maal secara langsung oleh para Muzakki yang sangat membutuhkan karena ketiadaan pangan atau karena mengalami musibah. Pola ini merupakan program jangka pendek dalam mengatasi permasalahan umat.

Kedua, Konsumtif kreatif, maksudnya zakat yang diwujudkan dalam bentuk barang konsumtif dan digunakan untuk orang miskin dalam mengatasi permasalahan sosial dan ekonomi yang dihadapinya. Bantuan tersebut antara lain berupa alat sekolah dan beasiswa untuk para pelajar, bantuan sarana ibadah seperti sarung dan mukena, bantuan alat pertanian seperti cangkul untuk petani, gerobak jualan untuk pedagang kecil, dan sebagainya.

Ketiga, Produktif konvensional, maksudnya zakat diberikan dalam bentuk barang produktif, dimana dengan menggunakan barang tersebut, para Mustahiq dapat menciptakan suatu usaha, seperti pemberian bantuan ternak kambing, sapi perahan atau untuk membajak sawah, alat pertukangan, mesin jahit, dan sebagainya.

Keempat, Produktif kreatif, zakat yang diwujudkan dalam

${ }^{10}$ www.lazisnujabar.or.id/2016/01/strategi-fundraising-upaya-mengali. html?m=0, diakses pada 25 Juli 2016.

${ }^{11}$ Uzaifah, "Manajemen Zakat Pasca Kebijakan Pemerintah Tentang Zakat Sebagai Pengurang Penghasilan Kena Pajak”, hlm. 56-57. 
bentuk pemberian modal bergulir baik untuk permodalan proyek sosial seperti membangun sekolah, sarana kesehatan atau tempat ibadah bagi pengembangan usaha para pedagang atau pengusaha kecil. Tetapi disyaratkan bahwa memberikan zakat yang bersifat produktif haruslah mampu melakukan pembinaan dan pendampingan kepada para Mustahiq zakat dalam kegiatan usahanya, juga harus memberikan pembinaan rohani dan intelektual keagamaan mereka agar semakin meningkat kualitas keimanan dan keislaman mereka.

Kerjasama semua pihak, baik para Muzakki, lembaga zakat dan Mustahiq sangat diperlukan untuk optimalisasi distribusi zakat produktif. Adapun langkah-langkah distribusi zakat secara produktif adalah sebagai berikut;

a. Pendataan yang akurat sehingga yang menerima benarbenar orang yang tepat.

b. Pengelompokkan peserta ke dalam kelompok kecil, homogen baik dari sisi gender, pendidikan, ekonomi dan usia. Kemudian dipilih ketua kelompok, diberi pembimbing dan pelatih.

c. Pemberian pelatihan dasar.

Dalam pelatihan harus berfokus untuk melahirkan pembuatan usaha produktif, manajemen usaha, pengelolaan keuangan usaha dan lain-lain. Pada pelatihan ini juga diberi penguatan secara agama sehingga melahirkan anggota yang berkarakter dan bertanggung jawab.

d. Pemberian dana.

Dana diberikan setelah materi tercapai, dan peserta dirasa telah dapat menerima materi dengan baik. Usaha yang telah direncanakan pun dapat diambil. Anggota akan dibimbing oleh pembimbing dan mentor secara intensif sampai anggota tersebut mandiri untuk menjalankan usaha sendiri.

Konsep Islam dalam distribusi zakat adalah dengan mengantarkan hak zakat ini ke rumah-rumah atau tempat tinggal orang-orang yang berhak menerimanya, baik berasal dari kaum primitif maupun dari komunitas modern. Tanpa membebani 
mereka untuk datang dan menerima hak mereka. Ini karena, landasan dasar dari operasional zakat adalah distribusi langsung setelah pengumpulan dana zakat, distribusinya harus sesuai dengan kebutuhan dan maslahah yang telah ditetapkan dalam syari'ah. ${ }^{12}$

Zakat produktif adalah zakat yang diberikan kepada Mustahiq sebagai modal untuk menjalankan suatu kegiatan ekonomi, yaitu untuk mengembangkan dan menumbuhkan tingkat ekonomi dan potensi Mustabiq. ${ }^{13}$ Zakat akan memberikan dampak yang lebih luas (multiplier effect) dan menyentuh semua aspek kehidupan apabila distribusi zakat lebih diarahkan pada kegiatan yang bersifat produktif. Sebagaimana Jamal mengemukakan bahwa pemanfaatan zakat juga perlu dilakukan ke arah investasi jangka panjang. Hal ini bisa dalam bentuk; pertama, zakat dibagikan untuk mempertahankan insentif bekerja atau mencari penghasilan sendiri di kalangan fakir miskin. Kedua, sebagian dari zakat yang terkumpul, setidaknya 50\% digunakan untuk membiayai kegiatan yang produktif kepada kelompok masyarakat fakir miskin.

Alasan perlunya zakat didayagunakan ke hal yang bersifat produktif adalah berdasarkan pada beberapa keterangan Yusuf Qardhawi bahwa zakat bukan sekedar bantuan sewaktu-waktu kepada fakir miskin untuk meringankan penderitaannya, tetapi bertujuan menanggulangi kemiskinan, agar orang miskin menjadi berkecukupan selama-lamanya, mencari pangkal penyebab kemiskinan itu dan mengusahakan agar orang miskin itu mampu memperbaiki sendiri kehidupan mereka.

Didin Hafiduddin seperti yang dikutip oleh Yeni Saptia menjelaskan bahwa para ulama seperti al-Syafi'i, an-Nasa'i, dan yang lain menyatakan bahwa jika Mustahiq zakat memiliki kemampuan untuk berdagang, selayaknya ia diberi modal untuk usaha yang memungkinkan ia memperoleh keuntungan

${ }^{12}$ Yusuf al-Qardhawi, (2005), Spektrum Zakat dalam Membangun Ekonomi Kerakyatan, (Sari Narulita Penterjemah), Jakarta: Zikrul Hakim, hal. 55.

${ }^{13}$ Mila Sartika, (2008), "Pengaruh Pendayagunaan Zakat Produktif Terhadap Pemberdayaan Mustahiq pada LAZ Yayasan Solo Peduli Surakarta", Jurnal Ekonomi Islam, Vol. II, No. 1, Juli,. hal. 80. 
yang dapat memenuhi kebutuhan pokoknya. Jika Mustahiq tidak bekerja dan tidak memiliki keterampilan tertentu, menurut Syamsyudin ar-Ramli, kepadanya diberikan jaminan hidup dari zakat, misalnya dengan cara ikut menanamkan modal (dari uang zakat tersebut) pada usaha tertentu sehingga Mustahiq tersebut memiliki penghasilan dari perputaran uang zakat tersebut. ${ }^{14}$

Idealnya zakat yang diberikan itu harus bisa menyelesaikan problem kemiskinan dengan cara memberi peluang, pelatihan, pendidikan, motivasi dan modal riil untuk usaha. Dengan bekal-bekal itu para Mustahiq zakat bisa merubah nasibnya dan mendongkrak ekonominya. Dengan harapan pada tahun-tahun mendatang mereka sudah bukan lagi Mustahiq tetapi sudah menjadi Murakki yang menyisihkan sebagian hartanya untuk zakat.

Artikel ini merupakan hasil dari penelitian lapangan (field research). Objek yang dikaji adalah model fundraising dan distribusi dana ZIS di UPZ Desa Wonoketingal Kecamatan Karanganyar Kabupaten Demak. Pendekatan yang digunakan adalah pendekatan kualitatif, pendekatan kualitatif digunakan bertujuan untuk memahami model fundraising dan distribusi dana ZIS yang digunakan oleh UPZ Desa Wonoketingal Karanganyar Demak.

Sedangkan metode pengumpulan data yang digunakan pada penelitian ini adalah metode observasi, metode wawancara, dan dokumentasi. Manakala teknik analisis yang digunakan adalah analisis data model Miles and Huberman melalui tiga langkah meliputi; reduksi data (Data Reduction), penyajian data (Data Display), verifikasi (Conclution Drawing). ${ }^{15}$

\section{Deskripsi desa Wonoketingal}

Luas wilayah desa Wonoketingal adalah 547.100 hektar yang terdiri dari tanah sawah sebanyak 461.491 hektar dan tanah kering (pemukiman) sebanyak 85.609 hektar. Dimana jumlah

${ }^{14}$ Yeni Septia, "Determinasi Peningkatan Pendapatan Mustahiq dalam Penggunaan Dana Zakat Produktif”, Jurnal Ekonomi dan Bisnis Islam, Vol. IV, No. 2, Juni 2010, hlm. 150-151.

${ }^{15}$ Sugiyono, Metode Penelitian Pendidikan Pendekatan Kuantitatif, Kualitatif, dan R\&DD, (Bandung: Alfabeta 2008), hlm. 134. 
penduduk yang ada adalah 6.567 jiwa yang terdiri dari 3.236 orang laki-laki dan 3.331 orang perempuan, dan jumlah Kepala Keluarga (KK) sebanyak 1.753 orang. Mereka memiliki pekerjaan yang bermacam-macam diantaranya petani sebanyak 2.354 orang, buruh tani 602, swasta 505, Aparatur Negeri Sipil (ASN) sebanyak 274 , pengrajin 75 , pedagang 130 , montir 10 , jasa angkutan 10 , pensiunan 20 , dan yang lain $106 .{ }^{16}$

Dari data tersebut, maka mayoritas perekonomian desa Wonoketingal ditopang dengan bertani, buruh tani, buruh pabrik dan buruh bangunan. Sebagian lagi ada yang berdagagang, jasa transportasi barang, bengkel motor (mobil) dan jasa menjahit (konveksi). Sebagian besar sawah yang digarap mereka yang bertani adalah sawah milih sendiri meskipun ada yang sewa dari sawah Bondo Deso. ${ }^{17}$

Kemudahan akses pendidikan dan kesehatan juga terpenuhi di desa Wonoketingal. Desa Wonoketingal memiliki 1 Sekolah Dasar Negeri SDN), 1 Madrasah Ibtidaiyyah Negeri (MIN), 3 Taman Kanak-Kanak (TK), 3 Taman Pendidikan al-Quran TPQ), dan 2 Madrasah Diniyah. Bahkan Madrasah Ibtidaiyah Negeri (MIN) yang ada di Desa wonoketingal merupakan MIN terbaik se kabupaten Demak. Selain itu, di desa wonoketingal juga memiliki Yayasan Pendidikan Islam yang bernama Nahdhatus Sibyan. Yayasan ini mengelola Madrasah Tsanawiyah, Madrasah Aliyah dan juga pobdok pesantren sebagai asrama para siswa. ${ }^{18}$ Sementara akses kesehatan, desa Wonoketingal memiliki 1 puskesmas desa dengan 2 petugas kesehatan setingkat manteri, 2 polindes dengan petugas berpendidikan Bidan. ${ }^{19}$

Kualitas Sumber Daya Manusia (SDM) yang ada di desa Wonoketingal cukup baik. Hal ini karena mayoritas kalangan orang tua telah mengenyam pendidikan formal meskipun cukup Sekolah Dasar ataupun Sekolah Menengah. Sementara di kalangan Anak muda dan keluarga muda rata-rata lulusan Sekolah

${ }^{16}$ Dokumen Desa Wonoketingal, 2015.

${ }^{17}$ Dokumen Desa Wonoketingal, 2015.

${ }^{18}$ Wawancara dengan Pengurus Yayasan Nahdhatus Sibyan, 2016.

${ }^{19}$ Dokumen Desa Wonoketingal, 2015. 
Menengah Atas atau setingkat. Bahkan sekarang ini banyak penduduk desa Wonoketingal yang telah menyelesaikan jenjang pendidikan Perguruan Tinggi.

Pendidikan agama di desa Wonoketingal sangat ditekankan, di setiap musalla pasti ada majlis pengajian al-Quran, pengajian selapanan, dan pengkajian kitab fikih ataupun akidah. Sebagai contoh, pada setiap hari sabtu selalu dilaksanakan pengajian rutin yang diasuh oleh KH. Zamroni Zean (Penasehat UPZ Desa Wonoketingal). Selain itu untuk membekali generasi penerus juga didirikan Madrasah Diniyah yang proses belajar mengajarnya dilakukan di waktu sore, yaitu jam 14.00 - 16.30.

Ini karena, penduduk desa Wonoketingal 100\% muslim ${ }^{20}$ sehingga untuk menjalankan ajaran agama, penduduk desa Wonoketingal didukung dengan sarana prasarana yang berupa 3 masjid (masjid al-Hidayah merupakan tempat pusat kegiatan di desa Wonoketingal), beberapa musalla yang tersebar di setiap kawasan, pondok pesantren dan juga UPZ Desa yang dibentuk untuk membantu masyarakat dalam membayarkan zakat atau memberikan infak sedekah.

\section{UPZ Desa Wonoketingal}

Kegiatan pengumpulan zakat di desa Wonoketingal sudah dimulai sejak tahun 1990-an. Para tokoh masyarakat, pemuka agama dan Kepala Desa bermusyawarah untuk memulai kegiatan itu. Hal ini dilatarbelakangi karena mereka melihat potensi zakat di desa Wonoketingal yang sangat besar karena mayoritas penduduknya adalah petani. Petani di desa Wonoketingal dapat menggarap sawah dua kali dalam setahun sehingga setiap tahun ada dua kali panen yang berarti kegiatan pengumpulan zakat pertanian juga dua kali.

Setelah bermusyawarah, maka dibentuklah panitia pengumpul zakat desa. Pada saat itu panitia hanya mampu mengumpulkan sebanyak $435 \mathrm{Kg}$. padi. Padahal kalau dilihat dari jumlah petani dan sawah yang digarap tidak sebanding jika zakat yang terkumpul hanya sejumlah itu. Ini karena banyak anggota

${ }^{20}$ Dokumen Desa Wonoketingal, 2015. 
masyarakat yang menganggap remeh pada pembentukan panitia pengumpulan zakat. ${ }^{21}$ Malah sebagian masyarakat ada yang beranggapan bahwa panitia hanya mengumpulkan zakat dari masyarakat lalu digunakan untuk diri sendiri.

Tahun demi tahun dilalui oleh panitia dengan didukung oleh para tokoh agama dan Kepala Desa. Tokoh agama selalu mensosialisasikan kewajiban zakat pertanian dan manfaat zakat jika dikumpulkan di panitia. Akhirnya panen demi panen hasil pengumpulan zakat terus meningkat.

Setelah Undang-undang No. 38 tahun 1999 tentang Pengelolaan Zakat disahkan, tepatnya pada tahun 2001 panitia zakat desa didukung oleh Pemerintah Desa mengajukan ijin kepada BAZCAM Karanganyar, dan sejak saat itu dibentuklah BAZIS Desa Wonoketingal dengan kepengurusan yang telah disahkan oleh BAZCAM Karanganyar.

Pada bulan Februari 2016, BAZIS Desa Wonoketingal berubah nama menjadi UPZ Desa Wonoketingal berdasarkan SK BAZCAM Karanganyar No: 01/III/2016. Hal itu terjadi karena pada tahun 2011 ada revisi Undang-undang Pengelolaan Zakat dan diterbitkan Peraturan Pemerintah No. 14 tahun 2014 untuk mengatur Pelaksanaan Undang-undang No. 23 tahun 2011 tentang Pengelolaan Zakat.

UPZ Desa Wonoketingal mengangkat visi: Izæul Islam wa al-Muslimin (Kemulian Islam dan kaum Muslimin). Dengan misi yang dikembangkan sebagai berikut:

a. Meningkatkan kesadaran umat untuk membayar zakat;

b. Meningkatkan pendayagunaan zakat, infak dan sedekah;

c. Mengembangkan manajemen pengelolaan yang amanah, transparan, dan professional;

d. Meningkatkan kesejahteraan masyarakat dari muqakki ke mustabiq

e. Mengembangkan pola penggunaan dana yang bersifat pemberdayaan umat

Manakala semboyang yang selalu didengungkan oleh

${ }^{21}$ Wawancara dengan K.H. M. Nur Kamilin, Ketua UPZ Desa Wonoketingal, tanggal 17 Mei 2016. 
pengurus UPZ Desa Wonoketingal adalah "Ibda' bi Nafsik" (mulai dari diri sendiri). Maksudnya, sebelum para pengurus UPZ menarik zakat kepada masyarakat, pengurus harus membayarkan zakat kepada UPZ terlebih dahulu. Semboyan itu dijadikan pegangan oleh para pengurus agar masyarakat mau mengambil teladan dari para pengurus.

Sesuai dengan SK BAZCAM Karanganyar No: 01/ III/2016 tanggal 13 Februari 2016, susunan pengurus UPZ Desa Wonoketingal Karanganyar Demak periode 2016 - 2019 terdiri dari seorang pelindung, tiga orang penasehat, seorang ketua, seorang wakil ketua, seorang sekertaris, seorang bendahara, dan beberapa orang anggota. Dimana anggota pengurusa UPZ Desa Wonoketingat terbagi menjadi 6 wilayah sesuai dengan jumlah Rukun Warga (RW) di Desa tersebut.

\section{Kegiatan UPZ desa Wonoketingal}

Sejak UPZ Desa Wonoketingal disahkan, UPZ memiliki tiga kegiatan penting seperti yang ditetapkan dalam regulasi. Tiga kegiatan tersebut adalah pengumpulan, pendistribusian dan pendayagunaan.

Kegiatan pengumpulan yang dilakukan UPZ Desa Wonoketingal tidak hanya dana zakat saja, namun pengumpulan juga meliputi dana infak sedekah. Zakat yang dikumpulkan memasukkan zakat mal dan zakat fitrah. Sedangkan infak sedekah yang dikelola berupa santunan anak yatim dan dana kurban.

Sementara pendistribusian juga merupakan kegiatan yang dilakukan UPZ Desa Wonoketingal. Meskipun hal ini bertentangan dengan regulasi kita karena menurut Pasal 46 ayat (3) Peraturan Pemerintah No. 14 tahun 2014, UPZ tidak berhak mendistribusikan dana yang dikumpulkan. UPZ wajib menyetorkan dana yang terkumpul kepada BAZNAS induk yang membentuknya.

Kewajiban menyetorkan dana yang dikumpulkan UPZ ke BAZNAS baru disebutkan secara jelas pada PP No. 14 tahun 2014, sebelum ada PP ini tidak ada ketentuan yang mengatur. Sehingga pada umumnya UPZ yang ada mendistribusikan dana 
yang mampu dikumpulkan secara langsung. Dan hal inilah yang menyebabkan UPZ Desa Wonoketingal hingga sekarang tetap mendistribusikan dana yang dikumpulkan, baik berupa dana zakat maupun dana infak sedekah.

Manakala kegiatan pendayagunaan Mustabik pernah diterapkan oleh UPZ Desa Wonoketingal di tahun 2008. Yaitu dengan cara memberikan sejumlah dana zakat yang cukup untuk membeli sawah kepada Mustabik yang tidak memiliki sawah. Namun cara pendayagunaan ini dievaluasi setelah ditemukan bahwa mereka yang mendapat dana zakat untuk membeli sawah tidak digunakan seperti harapan UPZ, mereka mengunakan dana tersebut untuk memenuhi kebutuhan harian mereka. ${ }^{22}$

Belajar dari kasus tersebut, UPZ Desa Wonoketingal merubah model pendayagunaan dana zakat yang diterima. Di beberapa tahun terakhir UPZ memberikan bagian 25\% dana zakat yang terkumpul kepada gharim. Gharim yang dimaksud di sini adalah panitia pembangunan sarana ibadah dan pendidikan Islam yang ada di desa Wonoketingal yang memiliki hutang. UPZ menerima permohonan dari para panitia Mushala dan Madrasah yang memiliki hutang guna menyelesaikan bangunan sarana prasarana. $^{23}$

Selain tiga kegiatan penting di atas, regulasi juga mengamanahkan kepada setiap lembaga zakat untuk membuat laporan secara berkala. Hal itu telah dikerjakan oleh UPZ Desa Wonoketingal karena UPZ telah membuat laporan pertangungjawaban setiap selesai kegiatan. Biasanya laporan pertangungjawaban disampaikan kepada masyarakat di saat solat Jum'at. Selain itu laporan juga disampaikan kepada Badan Amil Zakat Kecamatan (BAZCAM) Karanganyar sebagai lembaga yang membentuk dan mengangkat pengurus UPZ Desa Wonoketingal.

${ }^{22}$ Wawancara dengan Bpk. Hadi Mulyono, Petugas distribusi UPZ Desa Wonoketingal, tangal 17 Mei 2016.

${ }^{23}$ Wawancara dengan K.H. M. Nur Kamilin, Ketua UPZ Desa Wonoketingal, tanggal 23 Mei 2016. 


\section{Model Fundraising Dana ZIS di UPZ Desa Wonoketingal}

Program lembaga zakat tidak akan berjalan tanpa adanya fundraising (pengumpulan dana). Keberhasilan dalam fundraising akan menentukan kegiatan distribusi dan pendayagunaan. Oleh sebab itu, strategi atau model fundraising suatu lembaga zakat harus dirancang sesuai dengan situasi dan kondisi.

Dari data yang terkumpul, UPZ Desa Wonoketingal selalu membuat perencanaan dengan cara musyawarah bersama antara pengurus UPZ dan pemerintah Desa. Mereka bermusyawarah disetiap akan melakukan fundraising dana tertentu, baik itu berupa zakat ataupun infak sedekah. Musyawarah bertujuan untuk menentukan target fundraising, model fundraising dan membuat daftar muqakei dan mustabik.. ${ }^{24}$

Hasil musyawarah akan disosialisasikan oleh pengurus UPZ Desa Wonoketingal yang mayoritas mereka adalah tokoh agama dan tokoh masyarakat. Sosialisasi biasanya dilakukan melalui pengajian-pengajian rutin, pertemuan RT, saat menjelang khutbah Jum'at, dan juga pada saat ada acara tertentu. Dukungan Pemerintah Desa sangat berperan dalam kesuksesan fundraising UPZ Desa Wonoketingal. Hal ini karena Pemerintah Desa memiliki kesepakatan tidak tertulis dengan UPZ dan masyarakat yang mengarap sawah satu hektar. Kesepakatan tidak tertulis itu mewajibkan masyarakat yang menggarap sawah satu hektar minimal harus menyerahkan satu kwintal $(100 \mathrm{~kg})$ zakat pertanian mereka kepada UPZ Desa Wonoketingal. ${ }^{25}$ Sedangkan selebihnya, petani (sebagai Muqaki) diberikan kebebasan untuk membagikan sendiri kepada Mustabik atau dibayarkan kepada UPZ Desa secara keseluruhan. ${ }^{26}$

\footnotetext{
${ }^{24}$ Wawancara dengan Moh. Rosyad Ulwi, Sekertaris UPZ Desa Wonoketingal, tanggal 17 Mei 2016.

${ }^{25}$ Pada kondisi normal, umumnya satu hektar dapat menghasilkan padi antara enam ton hingga delapan ton. Dan telah diketahui bahwa zakat pertanian adalah 10\% jika diairi tanpa biaya atau 5\% jika diari dengan biaya. Sehingga petani yang menggarap sawah satu hektar berkewajiban mengluarkan zakat enam kwintal atau lebih sesuai dengan hasilnya.
}

${ }^{26}$ Wawancara dengan K.H. Zamroni Zaen, Penasehat UPZ Desa 
Dalam fundraising, UPZ Desa Wonoketingal tidak hanya mengumpulkan dana zakat saja, namun pengumpulan juga dilakukan pada dana infak sedekah. Zakat yang dikumpulkan pun memasukkan zakat mal dan zakat fitrah. Sedangkan infak sedekah yang dikelola berupa santunan anak yatim dan dana kurban. Jumlah dana ZIS yang terkumpul pada tahun 2013 - 2015 dapat dilihat dalam tabel 4.1 berikut:

\section{Tabel 1}

Jumlah Dana Zakat, Infak dan Sedekah yang Dikumpulkan UPZ Desa Wonoketingal

\begin{tabular}{|c|c|c|c|c|}
\hline No. & Jenis Dana & 2013 & 2014 & 2015 \\
\hline 1 & Zakat Mal & Rp 167.559.800,- & Rp 153.628.800,- & Rp 189.480.200,- \\
\hline 2 & Zakat Fitrah & Rp 19.108.800,- & Rp 21.184.800,- & Rp $22.824 .000,-$ \\
\hline 3 & Santunan Yatim & Rp 54.875.000,- & Rp 59.676.000,- & $\begin{array}{ll}\mathrm{Rp} & 64.735 .000,-\end{array}$ \\
\hline 4 & Dana Kurban & Rp 311.600.000,- & Rp 229.744.000,- & Rp 355.950.000,- \\
\hline & Jumlah & Rp 553.138.600,- & Rp 465.897.600,- & Rp 632.989.200,- \\
\hline
\end{tabular}

Sumber: Laporan UPZ Desa Wonoketingal 2013-2015.

Tabel di atas menunjukkan bahwa ada dua kategori dana yang dikumpulkan oleh UPZ Desa Wonoketingal, yaitu dana zakat dan dana infak sedekah. Zakat yang dimaksud meliputi zakat mal yang dikumpulkan setiap panen dan zakat fitrah yang dikumpulkan di akhir bulan Ramadhan. Biasanya dalam satu tahun zakat pertanian dikumpulkan dua kali karena petani Desa Wonoketingal bisa menanam padi dua kali dalam satu tahun. Sebagai contoh, pada tahun 2015 zakat mal yang terkumpul sebesar Rp 189.480.200,- dana tersebut berasal dari panen pertama sebesar Rp 99.605.500,- dan panen kedua sebesar 89.874.700,-. Semestinya yang terkumpul di UPZ Desa Wonoketingal di setiap panen ada yang berupa padi dan ada yang berupa uang tunai. Namun untuk keperluan pelaporan, maka yang berupa padi dinilai dengan nilai wajar pada saat penerimaan seperti yang diatur dalam PSAK 109. Manakala zakat fitrah yang mampu dikumpulkan UPZ pada tahun 2015 adalah sebesar $2.853 \mathrm{~kg}$ beras, oleh karena nilai beras pada saat itu Rp 8.000, - per kilogram, maka dalam 
laporan ditulis sebesar Rp. 22.824.000,-.

Dana infak sedekah yang dapat dikumpulkan oleh UPZ Desa Wonoketingal meliputi dana untuk santunan anak yatim dan dana kurban. Dana santunan anak yatim dikumpulkan setiap menjelang tanggal 10 Muharram dan yang terkumpul dari masyarakat pada tahun 2015 mencapai Rp 64.735.000,- Sedangkan dana kurban dikumpulkan menjelang hari raya Kurban yang pada tahun 2015 terkumpul dana sebanyak Rp 355.950.000,-. Semestinya tidak semua dana kurban berupa danai tunai, sebagian ada yang berupa hewan kurban.

Keberhasilan fundraising UPZ Desa Wonoketingal seperti yang disebutkan pada table di atas tidak terlepas dari model fundraising yang digunakan oleh UPZ tersebut. Selain sosialisasi yang dilakukan oleh setiap pengurus UPZ Desa Wonoketingal kepada masyarakat, pengurus UPZ desa Wonoketingal juga mendatangi langsung ke para petani yang mengarap sawah cukup luas ataupun donatur. Hal ini langsung dilakukan oleh ketua UPZ didampingi oleh pengurus yang lain. ${ }^{27}$ Model fundraising ini dirasa cukup jitu karena ada pendekatan personal dengan masyarakat sehingga mereka mau menyetorkan zakat ataupun infak sedekah mereka kepada UPZ Desa Wonoketingal.

Selain itu, anggota pengurusa UPZ Desa Wonoketingat yang terbagi menjadi 6 wilayah memiliki tugas mendatangi rumah warga secara langsung. Hal itu dilakukan setiap akan mengumpulkan dana tertentu, baik berupa dana zakat ataupun dana infak sedekah. Setiap anggota pengurus yang terbagi menjadi 6 wilayah bertanggungjawab dalam pengumpulan dan pendistribusian di wilayahnya. Dalam mengumpulkan zakat, baik zakat mal ataupun zakat fitrah mereka datang ke rumah masingmasing warga sebanyak dua kali. Pertama mereka mengedarkan list kesanggupan warga untuk menyetorkan zakat ke UPZ Desa Wonoketingal dengan jumlah yang akan mereka bayarkan. Setelah itu, mereka akan menginformasikan kepada warga bahwa di hari tertentu mereka akan datang lagi untuk mengumpulkan uang,

${ }^{27}$ Wawancara dengan K.H. M. Nur Kamilin, Ketua UPZ Desa Wonoketingal, tanggal 23 Mei 2016. 
gabah, atau beras yang mereka bayarkan sesuai dengan yang telah disepakati oleh setiap warga dan tercatat di list pada kedatangan pertama. $^{28}$

Sedangkan untuk dana infak sedekah, warga akan mendatangi pengurus UPZ wilayah atau langsung ke pengurus harian untuk menyatakan kesanggupan. Hal itu dilakukan warga setelah sosialisasi program, seperti program santunan anak yatim atau program kurban melalui pengajian atau yang lain. Semua itu dilakukan oleh pengurus UPZ Desa Wonoketingal kepada warga Desa yang tinggal dan menetap di Desa Wonoketingal. ${ }^{29}$

Model fundraising lain yang digunakan oleh UPZ Desa Wonoketingal adalah dengan menelpon atau mengirim surat kepada penduduk asli Desa Wonoketingal yang kerja di luar kota seperti di Jakarta, Sumatera, Kalimantan dan kota lain. Biasanya model ini digunakan untuk mengumpulkan dana santunan anak yatim dan dana kurban. ${ }^{30}$

Dalam manajemen fundraising dana ZIS kita mengenal banyak model dan teknik yang bisa dilakukan. Pada dasarnya model fundraising dapat dibagi menjadi dua seperti yang disebutkan dalam kerangka teori. Dengan demikian kita dapat menyimpulkan bahwa dalam mengumpulkan dana ZIS, UPZ Desa Wonoketinggal menggabungkan dua model fundraising, yaitu Direct Fundraising dan Indirect Fundraising. Indirect fundraising digunakan untuk mensosialisasikan program melalui pengumuman di pengajian rutin ataupun pertemuan warga. Dan setelah itu, pengurus UPZ yang telah dibagi menjadi 6 wilayah melakukan pengumpulan secara langsung dengan mendatangi rumah warga. Kedua model itu dijalankan secara bersamaan oleh pengurus UPZ Desa Wonoketingal agar pengumpulan dana ZIS dapat optimal.

Sedangkan berbagai teknik yang dijelaskan dalam teori manajemen Fundraising tidak digunakan oleh UPZ Desa

${ }^{28}$ Wawancara dengan Karjiman, Bendahara UPZ Desa Wonoketingal, tanggal 23 Mei 2016.

${ }^{29}$ Wawancara dengan K.H. Zamroni Zein, Pengawas UPZ Desa Wonoketingal, tanggal 23 Mei 2016.

${ }^{30}$ Wawancara dengan Moh. Rosyad Ulwi, Sekertaris UPZ Desa Wonoketingal, tanggal 23 Mei 2016. 
Wonoketingal secara keseluruhan. Ini karena, UPZ Desa merupakan lembaga pengumpul dana ZIS yang memiliki objek tertentu dan mayoritas mereka adalah warga desa yang tinggal di desa itu, meskipun ada sebagian mereka yang bekerja di luar kota. Untuk mereka yang bekerja di luar kota, pengurus UPZ akan mengirimkan surat atau menelpon dan setelah itu dana ditransfer melalui rekening salam satu pengurus. Jadi UPZ Desa Wonoketingal tidak menyediakan rekening tersendiri untuk menerima dana ZIS.

\section{Model Distribusi dana ZIS di UPZ desa Wonoketingal}

Distribusi dana merupakan kegiatan lembaga zakat setelah lembaga tersebut mengumpulkan dana. Menurut Pasal 46 ayat (3) Peraturan Pemerintah No. 14 tahun 2014, UPZ tidak berhak mendistribusikan dana yang terkumpul. Ini karena UPZ wajib menyetorkan dana yang dikumpulkan ke BAZNAS yang membentuknya.

Regulasi tersebut belum dilaksanakan oleh UPZ Desa Wonoketingal karena UPZ ini sudah menjalankan kegiakan pengumpulan dan distribusi sebelum ada Peraturan Pemerintah No. 14 tahun 2014. UPZ Desa Wonoketingal hingga saat ini tetap mendistribusikan dana yang mampu dikumpulkan, baik berupa dana zakat maupun dana infak sedekah. Dari data yang didapat, UPZ memiliki mekanisme distribusi yang berbeda-beda sesuai dengan kategori dana, dan akan dijelaskan sebagai berikut;

Pertama, Zakat Mal, UPZ Desa Wonoketingal mendistribusikan dana dari zakat mal menjadi empat bagian sama besar. Empat bagian tersebut adalah, bagian untuk fakir, bagian untuk miskin, bagian untuk Amil dan bagian untuk Gharim. Jadi masing-masing mendapat $25 \%$ dari dana yang terkumpul. Kebijakan ini diambil oleh UPZ karena UPZ hanya menemukan empat golongan Mustabik di desa tersebut. ${ }^{31}$ Sebagai contoh, pada tahun 2015 masing-masing mustahik, termasuk Amil mendapatkan Rp 47.370.050,-. Semestinya hal ini bertentangan

${ }^{31}$ Wawancara dengan K.H. M. Nur Kamilin, Ketua UPZ desa Wonoketingal, tanggal 23 Mei 2016. 
dengan regulasi kita, ${ }^{32}$ karena dalam regulasi kita dissebutkan bahwa Amil mendapatkan hak atas dana yang terkumpul sesuai dengan syariat Islam. dan jika kita merujuk pada pendapat alSyafi'i, maka Amil maksimal mendapatkan bagian satu perdelapan $(12,5 \%)$ dari dana zakat yang terkumpul. Namun setelah dikonfirmasi kepada pihak UPZ, bagian yang diterima Amil tidak seluruhnya digunakan. Amil hanya mengunakan bagiannya untuk biaya operasional dan ujrah Mitsil para pengurus, dan sisanya akan dikembalikan kepada golongan (ashnaf) yang membutuhkan. Pada tahun 2015, Amil memiliki sisa dana sebesar Rp 26.851.050,- dan dana tersebut digunakan untuk fakir, miskin dan gharim. ${ }^{33}$

Kedua, Zakat Fitrah, mekanisme distribusi dana zakat fitrah yang dikumpulkan UPZ Desa Wonoketingal adalah dengan membagikan semua beras fitrah yang terkumpul ke seluruh Ketua Keluarga (KK) desa Wonoketingal secara merata, UPZ sebagai Amil tidak mengambil bagian sama sekali. Keluarga yang masuk kategori fakir dan miskin akan mendapat bagian dua kali lipat, sedangkan keluarga yang tidak masuk kategori fakir miskin akan mendapat satu bagian. Mekanisme lain yang ditetapkan adalah memindah beras fitrah dari RW 1, 2, dan 3 ke RW 4, 5, dan $6 .^{34}$ Hal ini dilakukan agar beras fitrah tidak kembali kepada orang yang membayarnya sebagaimana pendapat al-Syafi'i.

Ketiga, Santunan Anak Yatim, dari dana santunan anak yatim yang terkumpul, UPZ Desa Wonoketingal membagikan secara sama kepada seluruh anak yatim yang terdaftar. Sebagai contoh, pada tahun 2015 ada 31 anak yatim yang telah terdaftar di UPZ Desa Wonoketingal sehingga masing-masing anak yatim mendapat santunan sebesar Rp 2.085.000,-. Dalam kegiatan ini, UPZ sebagai lembaga pengumpul tidak mengambil bagian dari dana yang terkumpul. UPZ hanya sebagai mediator antara para pemberi infak sedekah dan anak yatim. Penyerahan santunan anak yatim dilaksanakan bersamaan dengan pengajian peringatan

${ }^{32}$ Pasal 67 Peraturan Pemerintah No. 14 Tahun 2014.

${ }^{33}$ Wawancara dengan Bpk. Karjiman, Bendahara UPZ Desa Wonoketingal tanggal 23 Mei 2016 dan berdasarkan data laporan keuangan.

${ }^{34}$ Wawancara dengan Moh. Rosyad Ulwi, Sekertaris UPZ Desa Wonoketingal, tanggal 23 Mei 2016. 
sepuluh Syuro. ${ }^{35}$

Keempat, Hewan Kurban, pada tahun 2015 UPZ Desa Wonoketingal menerima hewan kurban sebanyak 26 ekor kerbau dan 12 ekor kambing. Kegiatan penyembelihan disentralkan di halaman parkir masjid al-Hidayah. Sedangkan untuk distribusi, panitia menentukan kepanitiaan per RW dan di setiap RW dibantu oleh panitia per RT. Pada tahun 2015 UPZ menyediakan 2000 bungkus daging kurban yang setiap bungkusnya terdiri dari $3 \mathrm{~kg}$. jumlah tersebut disesuaikan dengan jumlah Ketua Keluarga (KK) yang ada di desa Wonoketingal saat ini yang mencapai hampir 2000 KK. Bagi orang yang ikut kurban (Mudhahi) akan mendapatkan bagian tambahan maksimal 4 bungkus. Dalam hal dana kurban, UPZ juga tidak mengambil bagian dari dana yang terkumpul, UPZ hanya membebankan biaya operasional kepada setiap Mudhahi yang ikut syirkah hewan kurban.

Dari keempat jenis dana yang dikelola UPZ Desa Wonoketingal, UPZ Desa Wonoketingal hanya mengambil bagian dari dana zakat mal saja. Hal ini karena, UPZ Desa Wonoketingal dibentuk untuk syiar agama dan untuk Izzul Islam wal Muslimin seperti yang diungkapkan oleh KH. M. Nur Kamilin selaku ketua UPZ Desa Wonoketingal. ${ }^{36}$ Sedangkan ditinjau dari mekanisme distribusi dana zakat fitrah, dana santunan anak yatim dan hewan kurban yang diterapkan UPZ Desa Wonoketingal juga tidak bertentangan dengan regulasi yang ada.

Menurut regulasi zakat, amil bertugas untuk mendayagunakan dana zakat yang diterima untuk para Mustahiq. Telah disebutkan di atas bahwa pendayagunaan Mustabik pernah diterapkan oleh UPZ Desa Wonoketingal pada tahun 2008. Yaitu dengan memberikan sejumlah dana zakat yang cukup untuk membeli sawah kepada sebagian orang fakir. Namun cara ini dievaluasi setelah ditemukan bahwa mereka tidak megunakan dana tersebut seperti harapan UPZ. ${ }^{37}$ Lalu di beberapa tahun

${ }^{35}$ Wawancara dengan K.H. M. Nur Kamilin, Ketua UPZ desa Wonoketingal, tanggal 23 Mei 2016.

${ }^{36}$ Wawancara dengan K.H. Zamroni Zein, Penasehat UPZ Desa Wonoketingal, tanggal 23 Mei 2016.

${ }^{37}$ Wawancara dengan K.H. Zamroni Zein, Penasehat UPZ Desa 
terakhir ini UPZ memberikan bagian 25\% dana zakat yang terkumpul kepada gharim. Gharim yang dimaksud adalah panitia pembangunan sarana ibadah dan pendidikan Islam yang ada di desa Wonoketingal yang memiliki hutang. UPZ menerima permohonan dari para panitia mushala dan madrasah yang memiliki hutang guna menyelesaikan bangunan yang mereka kerjakan. ${ }^{38}$ Diantara gharim yang banyak mendapat dana zakat adalah panitia pembangunan Yayasan Pendidikan Islam Nahdhatus Shibyan yang mengembangkan pendidikan Madrasah Tsanawiyah, Madrasah Aliyah dan pesantren sebagai asrama.

Dalam manajemen distribusi dan pendayagunaan dana ZIS kita mengenal empat model seperti yang disebutkan dalam kerangka teori. Maka berdasarkan data di atas dapat disimpulkan bahwa dalam mendistribusikan dan mendayagunakan dana ZIS, UPZ Desa Wonoketinggal menerapkan dua model distribusi, yaitu model konsumtif tradisional dan model produktif kreatif. Model konsumtif tradisional digunakan untuk mendistribusikan zakat fitrah, zakat mal bagi fakir miskin, dan dana infak sedekah, baik yang berupa dana santunan anak yatim ataupun pembagian daging kurban. Sedangkan model produktif kreatif digunakan untuk distribusi dana zakat mal yang diperuntukkan bagi gharim. Hal ini karena gharim difokuskan pada panitia pembangunan tempat ibadah ataupun lembaga pendidikan.

\section{Simpulan}

Berdasarkan pembahasan tersebut di atas, maka dapat disimpulkan bahwa UPZ Desa Wonoketinggal menggabungkan dua model fundraising, yaitu Direct Fundraising dan Indirect Fundraising. Indirect fundraising digunakan untuk mensosialisasikan program melalui pengumuman di pengajian rutin ataupun pertemuan warga. Dan setelah itu, pengurus UPZ yang telah dibagi menjadi 6 wilayah melakukan pengumpulan secara langsung dengan mendatangi rumah warga. Kedua model itu dijalankan

Wonoketingal, tanggal 23 Mei 2016.

${ }^{38}$ Wawancara dengan Bpk. KH. M. Nur Kamilin, Ketua UPZ Desa Wonoketingal, tanggal 23 Mei 2016. 
secara bersamaan oleh pengurus UPZ Desa Wonoketingal agar pengumpulan dana ZIS dapat optimal.

Sementara model distribusi dana ZIS yang diterapkan UPZ Desa Wonoketinggal adalah model konsumtif tradisional dan model produktif kreatif. Model konsumtif tradisional digunakan untuk mendistribusikan zakat fitrah, zakat mal bagi fakir miskin, dan dana infak sedekah, baik yang berupa dana santunan anak yatim ataupun pembagian daging kurban. Sedangkan model produktif kreatif digunakan untuk distribusi dana zakat mal yang diperuntukkan bagi gharim. 


\section{DAFTAR PUSTAKA}

Ahmad Juwaini, (2015), "Manajemen Mutu Lembaga Zakat", (Makalah Seminar Internasional dengan tema "Stengthening Zakat for Socio Economic Development, UIN-Malang, Malang 16 November 2015)

April Purwanto (2009), Manajemen Fundraising bagi Organisasi Pengelola Zakat, Yogyakarta: Sukses.

Fakhruddin, (2015), "Rekontruksi Fikih Zakat: Menuju Era Baru Fikih Zakat", (Makalah Seminar Internasional dengan tema "Stengthening Zakat for Socio Economic Development, UIN-Malang, Malang 16 November 2015)

Mila Sartika, (2008), "Pengaruh Pendayagunaan Zakat Produktif Terhadap Pemberdayaan Mustahiq pada LAZ Yayasan Solo Peduli Surakarta", Jurnal Ekonomi Islam, Vol. II, No. 1, Juli, 2008.

Nor Asiah Mohamad, (2015), “The Opportunities and Challenges in Zakat Administration in the Muslim World", (Makalah Seminar Internasional dengan tema "Stengthening Zakat for Socio Economic Development, UIN-Malang, Malang 16 November 2015)

Peraturan Pemerintah No. 14 Tahun 2014 Tentang Pelaksanaan Undang-Undang No. 23 Tahun 2011 Tentang Pengelolaan Zakat.

Sri Budi Cantika Yuli, (2005), Manajemen Sumber Daya Manusia, Malang: UMM Press.

Sudirman Hasan, (2015), "Introducing Zakat Based Mocrofinance: Bank of Zakah el-Zawa”, (Makalah Seminar Internasional dengan tema "Stengthening Zakat for Socio Economic Development, UIN-Malang, Malang 16 November 2015) 
Sudirman, (2007), Zakat dalam Pusaran Arus Modernitas, Malang: UIN-Malang Press.

Sugiyono, (2008), Metode Penelitian Pendidikan Pendekatan Kuantitatif, Kualitatif, dan R\&D, Bandung: Alfabeta.

Undang-undang No. 23 Tahun 2011 Tentang Pengelolaan Zakat

Uzaifah, (2010), “Manajemen Zakat Pasca Kebijakan Pemerintah Tentang Zakat Sebagai Pengurang Penghasilan Kena Pajak", Jurnal Ekonomi Islam, Vol. IV, No. 1, Juli 2010.

www.lazisnujabar.or.id/2016/01/strategi-fundraising-upayamengali.html?m=0, (diakses tanggal 25 Juli 2016)

Yeni Septia, (2010), "Determinasi Peningkatan Pendapatan Mustahiq dalam Penggunaan Dana Zakat Produktif", Jurnal Ekonomi dan Bisnis Islam, Vol. IV, No. 2, Juni 2010.

Yusuf al-Qardhawi, (1985), Musykilah al-Faqr wa Kaifa Alajaha alIslam, Beirut: Muassasah al-Risalah.

Yusuf al-Qardhawi, (2005), Spektrum Zakat dalam Membangun Ekonomi Kerakyatan, (Sari Narulita Penterjemah), Jakarta: Zikrul Hakim. 